\title{
Monetary Policy Instruments and the Control of Inflation in Nigeria: A Time-Series Analysis
}

\author{
Clement Korgbeelo $^{1 *}$, Deebii Nwiado ${ }^{1}$ \\ ${ }^{\top}(\mathrm{Ph} . \mathrm{D})$; Department of Economics, Ignatius Ajuru University of Education, Rumuolumeni, Port Harcourt, Nigeria
}

\section{*Corresponding Author}

Clement Korgbeelo

\section{Article History}

Received: 09.03.2021

Accepted: 14.04 .2021

Published: 24.04.2021

\begin{abstract}
Inflation is one of the major macroeconomic problems facing Nigeria today. Over the years, the Central Bank of Nigeria (CBN) has been using monetary policy instruments in tackling inflation in the country. However, the menace of inflation has not been adequately put under control. It is therefore necessary to examine the effectiveness of monetary policy instruments in combating inflation in Nigeria: This study therefore examines the efficacy of monetary policy instruments in fighting inflationary pressure in Nigeria. Specifically, the study examines the impact of reserve requirement, liquidity ratio, treasury bill rate, monetary policy rate and money supply on inflation in Nigeria. Annual time-series data from 1981 to 2019 were used for the study. A variety of analytical techniques such as Phillips-Perron unit root test, Johansen cointegration test and error correction model was used in analyzing the data. The findings indicated that reserve requirement, liquidity ratio, monetary policy rate and Treasury bill rate have no significant influence on inflation in Nigeria. The main recommendation is that there should be a proper co-ordination of monetary and fiscal policies to reduce conflicts in the implementation of both policies.
\end{abstract}

Keywords: Monetary policy instruments, inflation control, ARDL.

\section{INTRODUCTION}

Inflation is one of the major macro-economic problems facing Nigeria today. It is a monster that threatens the economy. Inflation erodes the purchasing power of money thereby, deteriorating the standard of living of the people. There is indeed a general consensus that persistent rise in prices undermines the role of money as a store of value and frustrates savings, investment and growth [1]. Ajayi and Ojo [2] believe that there exists a long-run inverse relationship between inflation and economic growth in Nigeria. The problem of inflation has made price stability one of the major monetary policy objectives to be pursued in most developing countries. Consequently, in Nigeria, the core mandate of the Central Bank of Nigeria is to maintain price stability. That is, to keep prices from persistently rising while also maintaining balance of payments and exchange rate stability within the context of a growing economy [3]. To effectively carry out its function of price stabilization, the Central Bank of Nigeria has, in its policy kit, a variety of instruments. These instruments which are generally referred to as monetary policy instruments include monetary policy rate, open magnet operation, liquidity ratio, etc [4]. Since its inception in 1959, the Central Bank of Nigeria (CBN) has been playing the traditional role expected of an apex monetary authority in the country. This role is anchored on the use of monetary policy instruments to achieve price stability and other macroeconomic policy objectives. In spite of this, the country has been experiencing high and rising levels of inflation [5]. It is therefore necessary to examine the extent to which the CBN has been able to use the instruments of monetary policy to tame the inflationary pressure in the country.

Furthermore, there is a plethora of empirical evidence on the impact of monetary policy on inflation in Nigeria. However, there appears to be no concensus on the findings of such empirical studies. While some studies $[6,5,7,8]$ showed that monetary policy is effective in taming inflationary pressures in Nigeria, others [9-12] have shown that monetary policy has no significant influence on inflation in Nigeria. Also, at the theoretical level, the effectiveness of monetary policy in macroeconomic stabilization has been a subject of great debate among economists. While the monetarists are of the view that monetary policy is more effective, the Keynesians hold the contrary view that it is fiscal

Copyright (C) 2021 The Author(s): This is an open-access article distributed under the terms of the Creative Commons Attribution 4.0 International License (CC BY-NC 4.0) which permits unrestricted use, distribution, and reproduction in any medium for noncommercial use provided the original author and source are credited. 
policy that is more effective [13]. It has also been asserted by some economists that monetary policy can only play limited roles in less developed economies due to the low level of development of their financial markets and the absence of a wide variety of financial instruments [14-17].

Based on the foregoing, this study therefore is an attempt to contribute to the debate and to revalidate the assertions by analyzing the effectiveness of monetary policy instruments in tackling inflationary pressure in Nigeria. The rest of the paper is divide into four sections. Section two deals with literature review and conceptual issues. Section three is concerned with methodology. Section four is devoted to data analysis and presentation of results while section five focuses on discussion of findings, conclusions and recommendations for policy.

\section{LITERATURE REVIEW \\ Conceptual Clarifications \\ The Concept of Inflation}

Inflation refers to a sustained and persistent upward trend in the general level of prices. It is the persistent, sustained, and appreciable rise in the general level of prices of goods and services [13]. It is a quantitative measure of the rate at which the average price level of a basket of selected goods and services in an economy increases over some period of time. Often express in percentage, inflation thus indicates a decrease in the purchasing power of a nation's economy. [3].

Based on its general causes, inflation be categorized into demand-pull, cost-push, built-in inflation, etc. We can also categorize inflation based on its speed and intensity. In this sense we have creeping inflation, walking inflation, galloping inflation and hyper-inflation $[18,19,13]$.

\section{The Concept of Monetary Policy}

Monetary policy refers to the actions taken by a country's monetary authority (i.e, the central bank) to control the volume, direction, cost and availability of money and credit in order to achieve predetermined macroeconomic objectives [3]. The main objectives of monetary policy are sustainable economic growth, price stability, full employment equilibrium, exchange rate stability and balance of payments equilibrium [20].

Depending on the stage of development of a country's financial system, central banks use a member of instruments to conduct monetary policy. These instruments are of two types: the quantitative instruments and the qualitative instruments. The quantitative instruments, also referred to as general or indirect instruments, are meant to regulate the overall level of credit in the economy through the deposit money banks. They operate through the market by influencing underlying demand and supply conditions. They are therefore also referred to as market- based instruments or instruments of market intervention since they generally change the supply of banks' reserves through transactions with banks and non-banks at market related prices and on a voluntary basis [21]. The most commonly used quantitative instruments include bank rate or monetary policy rate, open market operation, reserve requirement, treasury bill, liquidity ratio, etc [22]. The qualitative instruments, also called selective or direct instruments, set or limit either prices (i.e. interest rates) or quantities of credit through regulations. They mainly aim at the balance sheets of deposit money banks. The credit objectives may include rationing the credit, directing the flow of credit to preferred sectors of the economy, etc. The direct instruments include selective credit control, individual or aggregate loan ceilings, credit rationing, margin requirement, moral suasion and special directives [23].

\section{Overview of the Conduct of Monetary Policy in Nigeria}

Over the years, the objectives of monetary policy in Nigeria have remained the attainment of internal macroeconomic stability and external balance of payments stability. However, emphasis on techniques to achieve the objectives have been changing over the years [22, 7]. There have been two major phases in the pursuit of monetary policy in Nigeria, namely, before and after 1986. The first phase which placed emphasis on direct monetary controls lasted from 1959 to 1985 . Between 1960 and 1962, the CBN operated a passive monetary policy regime in which the focus was on development and maintenance of a sound domestic currency with the need to ensure greater supply of credit. In 1962, the focus change to economic development issues. In the later part of 1964 and 1965, the main focus of monetary policy changed to the achievement of balance of payments equilibrium with credit restraint as the main instrument. This was lifted in November 1966 to enable government have enough resources to prosecute the civil war However, due to post-war inflationary pressures, the CBN reversed back to monetary restraint for the period 1972 to 1976; which continued till 1985 [24, 23].

Due to the worsening economic situation, it became expedient to eliminate unnecessary economic controls from 1986. This led to the introduction of the Structural Adjustment Programme (SAP) in July 1986 with the main aim of reducing the hitherto excessive controls so as to ensure more efficient market oriented allocation of resources. This marked the beginning of the era of indirect monetary control which relies on market mechanism. In line with the 
liberalization policy of the SAP, there was a shift from the hitherto repressive direct monetary control method to an indirect approach based on the use of market instruments in monetary management. During this phase, two major policy regimes can be identified, namely, the short-term monetary policy horizon for the period 1986 to 2001 and the medium term monetary policy horizon for the period 2002-date [3, 25-27].

Since its inception, the CBN has used two monetary policy frameworks for the implementation of monetary policy. These are exchange rate targeting and the monetary targeting frameworks. The exchange rate targeting framework covered the period 1959 to 1973 while the monetary targeting framework has been in use from 1974 to data. The change from exchange rate targeting to monetary targeting was significantly influenced by the collapse of the Bretton Woods system of fixed exchange rates in 1974 and the change in strategy to demand management as a way of taming inflationary pressures and balance of payments imbalances [2, 23, 28, 22].

\section{Inflationary Trends in Nigeria: An Overview}

We can broadly phase the inflationary trends in Nigeria into four periods. The first phase is the oil boom era of the 197 os. The sudden increase in government oil revenue brought about spending spree, fiscal dominance and significant macro-economic imbalances during the $197 \mathrm{os}$. The inflation rate averaged 33.7 percent in 1975 . This was as a result of the increased money supply, excess liquidity and the doubling of the minimum wage as recommended by the Udoji Commission [29]. To tackle the inflationary pressure, there was the need to increase output and create employment opportunities. Thus, imports were liberalized and banks were advised to extend more credit to the productive sectors of the economy. Consequently, the inflation rate dropped to $11.8 \%$ in 1979 [30].

The second phase was during the oil glut era of the 1980s. The period was characterized by continued overvaluation of the naira even as oil revenue fell drastically leading to significant distortions, import dependence and balance of payments problems. Consequently, the inflation rate rose to $41.2 \%$ in 1984 [27]. Due to favourable weather conditions and contractionars fiscal and monetary policies, the inflation rate dropped significantly to 5.5 percent and 5.4 percent in 1985 and 1986 respectively [31]. As a result of the 1987-1988 drought and the lag-in-effect of the 1986 devaluation, the inflation rate rose to 10.0percent and 59.0 percent in 1987 and 1988 respectively. Due to the growth in money supply and increased devaluation, the inflation rate remained above 50 percent in 1989 [1].

The third phase in Nigeria's inflationary trend was the 1990's. Nigeria experienced serious inflationary pressures as a result of increased monetary growth and fiscal expansion during the 1990's. The inflation reached its highest rate of about $79.9 \%$ in 1995 . To curb the rising inflation rate, the government put in place some measures including effective monetary policy, fiscal prudence and exchange rate stabilization. Consequently, the inflation rate dropped to 6.6 percent in 1999 [32].

The fourth phase in Nigeria's inflationary trend is the period covering 2000 to date. Because of the increase in the pump-price of petroleum products, the rate of inflation increased to 18.9 percent in 2001 . Increased political activities during the 2003 general elections led to increased aggregate demand which affected the inflationary situation in the country. The inflation rate which was 14 percent in 2003 declined to 6.6 percent in 2007 . It however jumped to 15.1 percent in 2008 but later dropped to 12.1 percent in 2009. The relatively high inflation rates in 2008 and 2009 could be attributed to the global financial crises [33]. The inflation rate increased to 13.8 percent in 2010. By 2014, the inflation rate stood at 8.0 percent. It however rose to 9.5 per cent in 2015 . In 2016 that the country plunged into recession, the figure rose to 15.7 percent and later increased to 16.5 percent in 2017 . This was mainly as a result of higher energy prices, high costs of inputs and currency depreciation, Ministry of Budget \& National Planning, 2017. The inflation rates stood at 12.1 percent and 11.4 percent in 2018 and 2019 respectively.

\section{Theoretical Literature Review}

In this section some theories of inflation are reviewed. Theories of inflation are theories that seek to explain the causes of the increase in the general level of prices. These theories include the classical quantity theory of money, the Keynesian theories of inflation, the monetarist theory and the structuralist theory of inflation.

The classical quantity theory of money is the oldest theoretical proposition that explains price increases. The quantity theory which started with Jean Bodin in the mid- $16^{\text {th }}$ century has undergone significant refinements and extension in the late $17^{\text {th }}$ and $18^{\text {th }}$ centuries by John Locke, Richard Cantillon and David Hume. The basic propositions of the classical quantity theory have been further expounded by the likes of Milton Friedman, Philip Cogan, Allen Melter and Karl Brunner [34, 35].

The quantity theory has been explained using two similar formulations. These are the equation of exchange of Irving Fisher and the cash-balance approach developed by a group of Cambridge economists like Pigou, Marshal, 
Robertson and Keynes [13]. The central theme of the quality theory of money is that changes in the general level of prices are determined mainly by changes in the quantity of money in circulation [3].

There are two Keynesion theories of inflation. These are the demand-pull and cost-push theories of inflation. The demand pull theory works through the investment-savings mechanism. According to Keynes, excess of investment over savings gives rise to an inflationary gap which results into excess aggregate demand. As a result of the excess aggregate demand, prices will rise and excess-demand inflation or demand-pull inflation is said to occur [36]. In the Keynesian theory of cost-push inflation, inflation is attributed to supply side factors, i.e., rising costs of production. According to Keynes, the main cause of increase in production costs is wage increase occasioned by powerful trade union activities [13].

The monetarist theory of inflation asserts that variations in the money supply have major influences on national output in the short-run and price levels over the long-run. According to the torch-bearer of the monetarist school, Professor Milton Friedman, "inflation is always and everywhere a monetary phenomenon in the sense that it is and can be produced only by a more rapid increase in the quantity of money than in output". Thus, the monetarist theory of inflation states that inflation is mainly caused by excessive expansion of money supply [37].

Another important theory of inflation is the structuralist theory. The structuralist theory of inflation explains inflation in developing countries in terms of market imperfections, distortions and structural regidities or bottlenecks of various types. According to the structuralists, these constraints or bottlenecks are of three types: (i) agricultural bottlenecks which make supply of agricultural products inelastic, (ii) resources constraint or government budget constraint, and (iii) foreign exchange bottlenecks which limit their ability to finance the necessary imports for economic development [38, 39].

\section{EMPirical Literature ReVIEW}

Some of the studies conducted on the effectiveness of monetary policy instruments in inflationary control are reviewed in this section.

Chinaemerem and Akujuobi [9] studied the relationship between inflation and monetary policy instruments in Nigeria and Ghana. The main conclusion from the study is that there is no strong and predictable nexus between monetary policy instruments and inflation in both countries. Similarly, Asshoff, Belke and Osowski [40] studied the impact of European Central Bank (ECB) unconventional monetary policy measures on inflation expectations in the Euro area. The findings showed that unconventional monetary policy measures lead to rise in inflation. Dabrowski, Paczynski and Rawdonowicz [41] analyzed the relationship between inflation and monetary policy in Russia. The results showed that money supply and inflation are related. Muco, Sanfey and Taci [42] studied the impact of monetary policy on inflation in Albania and found a weak link between money supply and inflation. Honore [43] established a significant positive nexus between money supply and inflation in Cameroun for the period 1980 to 2016. Similarly, Doan [44] found that money supply positively affects inflation in Vietnam.

In Nigeria, Ogbonna [45] used data for the period 1960 to 2008 to establish that money supply has no significant impact on inflation while exchange rate is effective on inflation. Nwosa and Oseni [46] studied the impact of exchange rate and interest rate on inflation in Nigeria for the period 1986 to 2010 and found causal nexus between exchange rate and inflation and between interest rate and inflation. Odior [10] established that monetary policy instruments have no significant impact on inflation in Nigeria. Onwachukwu [6] found that bank rate, deposit with the Central Bank, liquidity ratio and broad money supply have significant impact on inflation while exchange has no significant impact on inflation in Nigeria.

The findings of Apere and Karimo [5] is that monetary policy is effective in controlling inflation in Nigeria. Nwachukwu, Dibie and Ogudo [47] found that exchange rate has negative impact on inflation while broad money supply and interest rate are positively related to inflation in Nigeria. Ngerebo [11] found that monetary policy rate, treasury bill rate, primary lending rate, maximum lending rate and net domestic credit have no significant impact on inflation while savings rate, narrow money supply, broad money supply, net credit to government and credit to private sector have significant effect on inflation in Nigeria.

Akarara and Azebi [7] found that Treasury bill rate, exchange rate, money supply and monetary policy rate are effective in controlling inflation in Nigeria. Adodo, Akindutire and Ogunyemi [8] concluded that money supply and interest rate have significant influence on inflation in Nigeria. Ikezam [48] in his study established that currency in circulation and savings deposit have insignificant negative impact on inflation while demand deposit has significant negative relationship with inflation in Nigeria. Usman [49] found significant impact of money supply and exchange rate on inflation while monetary policy rate has no significant influence on inflation in Nigeria. Similarly, Okotori [26] found 
out that money supply and exchange rate have significant positive impact on inflation while interest rate has significant negative impact on inflation in Nigeria. Ogunmuyiwa [27] established that broad money supply and exchange rate have significant positive impact on inflation in Nigeria.

From the empirical literature reviewed, it observed that while some of the studies conducted in Nigeria showed that monetary policy instruments have significant impact on inflation, others showed that monetary policy instruments have no significant impact on inflation. The empirical evidence on the impact of monetary policy instruments on inflation in Nigeria is therefore mixed. It is also observed that some of the studies used variables that are not actually monetary policy instruments. Such variables include fiscal deficit, oil prices, government expenditure, gross domestic product, etc. This study therefore used core monetary policy instruments such as reserve requirement, liquidity ratio, Treasury bill rate, monetary policy rate and broad money supply to examine their effectiveness in controlling inflation in Nigeria.

\section{Methodology}

\section{Description of the Variables of the Study}

The variables used for this study are briefly explained below.

\section{Dependent Variable}

The dependent variable for this study is inflation rate. It is a measure of the annual percentage change of the consumer price index.

\section{Explanatory Variables}

The explanatory variables include the following:

i. Reserve Requirement: This is the Central Bank regulation that sets the minimum amount of reserves that deposit money banks must keep as a percentage of their total deposits.

ii. Liquidity Ratio: This is the ratio of a bank's liquid assets to its total liabilities.

iii. Treasury Bill Rate: Treasury bill are short-term money market securities issued by the Central Bank with maturity dates of one year or less. The Central Bank uses the Treasury Bill Rate to control the liquidity level in the banking system.

iv. Monetary Policy Rate: This is the interest rate at which the CBN lends money to the deposit money banks.

v. Money Supply: The broad money supply $\left(\mathrm{M}_{2}\right)$ includes narrow money supply (i.e currency in circulation and demand deposits) plus savings and time deposits, as well as foreign denominated deposits.

\section{Model Specification}

The model used for this study is specified based on the monetalists theory of inflation, and the empirical model used by Ngerebo [11]. However, the model was adopted with slight modification to accommodate the variables of this study.

The functional form on which the ordinary least squares (OLS) equation was based is expressed as follows: $\mathrm{INF}=(\mathrm{RR}, \mathrm{LR}, \mathrm{TBR}, \mathrm{MPR}, \mathrm{MS})$ 3.1

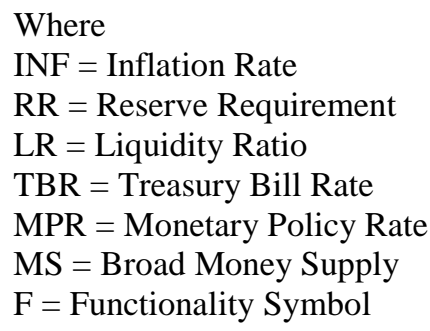

INF is the dependent variable while RR, LR, TBR, MPR and MS are the explanatory variables

The OLS multivariate regression equation based on the above mathematical model is expressed as follows:

$\mathrm{INF}=\beta_{0}+\beta_{1} \mathrm{RR}+\beta_{2}+\mathrm{LR}+\beta_{3} \mathrm{TBR}+\beta_{4} \mathrm{MPR}+\beta_{5} \mathrm{MS}+\mathrm{U} \ldots \ldots \ldots \ldots \ldots . . .2$

Where $\beta_{0}$ is he regression intercept, $\beta_{1}, \beta_{2}, \beta_{3}, \beta_{4}$ and $\beta_{5}$ are the regression coefficients of the parameters, and $U$ is the error term.

On apriori theoretical ground, we expect the following signs of the parameter estimates.

$\mathrm{INF}=\beta_{0}+\beta_{1} \mathrm{RR}+\beta_{2}+\mathrm{LR}+\beta_{3} \mathrm{TBR}+\beta_{4} \mathrm{MPR}+\beta_{5} \mathrm{MS}+\mathrm{U}$

$\left(\beta_{1}<0, \beta_{2}<0, \beta_{3}<0, \beta_{4}<0, \beta_{5}>0\right)$ 


\section{Nature and Sources of Data}

This study made use of annual time series data from 1981 to 2019. The data were obtained from the Central Bank of Nigeria annual statistical bulletin for 2019 and the Central Bank of Nigeria annual reports and statement of accounts for various years.

\section{Techniques of Data Estimation}

The ordinary least squares (OLS) multiple regression analysis was used in estimating the specified model. However, due to the nature of time-series data, the OLS regression technique was preceded by unit root test in order to check whether the series are stationary or not, and also, to determine the order of integration of the series. To this end, the Phillips-Perron unit root test was used in conducting the stationarity test. The results of the unit root test therefore necessitated the use of autoregressive distributed lag (ARDL) approach in estimating the specified model .

\section{Presentation of Results and Discussion of Findings \\ Presentation of Results \\ Descriptive Statistics}

The results of the descriptive statistics are presented in Table-1.

Table-1: Descriptive Statistics Results

\begin{tabular}{|l|l|l|l|l|l|l|}
\hline Variables & INF & RR & LR & MPR & TBR & LOG (MS) \\
\hline Mean & 18.91564 & 883.1241 & 47.77179 & 13.10513 & 13.80077 & 6.763488 \\
\hline Median & 12.90000 & 77.05000 & 46.80000 & 13.50000 & 12.00000 & 6.943200 \\
\hline Maximum & 72.80000 & 9578.540 & 75.80000 & 26.50000 & 57.00000 & 10.47330 \\
\hline Minimum & 5.400000 & 1.210000 & 29.10000 & 6.000000 & 5.000000 & 2.782663 \\
\hline Std. Dev. & 16.37888 & 2031.848 & 10.58753 & 4.109293 & 8.408542 & 2.575993 \\
\hline Skewness & 1.765944 & 2.724514 & 0.460226 & 0.737196 & 3.613073 & -0.102903 \\
\hline Kurtosis & 5.287059 & 10.44244 & 2.979755 & 4.519093 & 19.11656 & 1.606386 \\
\hline Jargue Bera & 28.77042 & 138.2580 & 1.377421 & 7.282392 & 506.9363 & 3.224839 \\
\hline Probability & 0.000001 & 0.000000 & 0.502223 & 0.026221 & 0.000000 & 0.199405 \\
\hline Sum & 737.7100 & 34441.84 & 1863.100 & 511.1000 & 538.2300 & 263.7761 \\
\hline Sum Sq. Dev. & 10194.17 & $1.57 \mathrm{E}+08$ & 4259.639 & 641.6790 & 2686.736 & 252.1581 \\
\hline Observations & 39 & 39 & 39 & 39 & 39 & 39 \\
\hline
\end{tabular}

Source: Authors' Computation from E-view 10.0

From Table-1 above, the mean values of the variables are 18.91564, 883.1241, 47.77179, 13.10513, 13.80077 and 6.763488 for INF, RR, LR, MPR, TBR and LOG (MS) respectively. The standard deviation result showed that RR with a standard deviation of 2031.848 is the most unstable variable while LOG (MS) with standard deviation of 2.575993 is the least unstable variable. The result of Skewness statistic indicates that, apart from LOG (MS) which is negatively skewed, all other variables are positively skewed. The Kurtosis statistic result shows that INF, RR, MPR and TBR are normally distributed while LR and LOG (MS) are platykurtic (i.e., their Kurtosis values are less than 3).

\section{Unit Root Test Results}

The results of the Phillips-Perron unit root test are presented in Table-2 below.

Table-2: Phillips-Perron Unit Root Test Results

\begin{tabular}{|c|c|c|c|c|c|c|c|}
\hline Variable & $\begin{array}{l}\text { Phillips-Perron } \\
\text { Test Statistic At } \\
\text { levels }\end{array}$ & $\begin{array}{l}1 \% \\
\text { Critical } \\
\text { Value } \\
\end{array}$ & $\begin{array}{l}5 \% \\
\text { Critical } \\
\text { Value } \\
\end{array}$ & $\begin{array}{l}\text { Phillips-Perron } \\
\text { Test Statistic } \\
\text { (At } 1^{\text {st }} \text { Diff.) }\end{array}$ & $\begin{array}{l}1 \% \\
\text { Critical } \\
\text { Value } \\
\end{array}$ & $\begin{array}{l}5 \% \\
\text { Critical } \\
\text { Value } \\
\end{array}$ & $\begin{array}{l}\text { Order } \\
\text { of } \\
\text { Integr. }\end{array}$ \\
\hline INF & -2.413801 & -3.615588 & -2.941145 & $-9.877913 *$ & -3.621023 & -2.943427 & $\mathrm{I}(1)$ \\
\hline LR & $-3.071252 * *$ & -3.615588 & -2.941145 & -16.52917 & -3.621023 & -2.943427 & $\mathrm{I}(0)$ \\
\hline RR & -2.892032 & -3.615588 & -2.941145 & $-12.65283 *$ & -3.621023 & -2.943427 & $\mathrm{I}(1)$ \\
\hline MPR & $-3.277189 * *$ & -3.615588 & -2.941145 & -16.92419 & -3.621023 & -2.943427 & $\mathrm{I}(0)$ \\
\hline TBR & $-5.349354 *$ & -3.615588 & -2.941145 & -19.79307 & -3.621023 & -2.943427 & $\mathrm{I}(0)$ \\
\hline LOG(MS) & -1.991352 & -3.615588 & -2.941145 & $-5.939544^{*}$ & -3.621023 & -2.943427 & $\mathrm{I}(1)$ \\
\hline
\end{tabular}

Source: Author's Computation from E-view 10.0

Note: * and $* *$ denote rejection of null hypothesis of unit root at the $1 \%$ and $5 \%$ levels of significance respectively.

From Table-2 above, LR, MPR and TBR are stationary at levels (i.e., I(0) at the 5\% and $1 \%$ levels of significance respectively. On the other hand, INF, RR and LOG (MS) are stationary after taking their first differences (i.e., 1(1) at the $1 \%$ level of significance. 


\section{ARDL Bounds Test Results}

The result of the autoregressive distributed lag (ARDL) bounds test for cointegration is shown in Table-3 below.

Table-3: ARDL Bounds Test Result

\begin{tabular}{|l|l|l|l|l|}
\hline F-Bounds Test & \multicolumn{4}{|l|}{ Null hypothesis: No Long-Run Relationship } \\
\hline Test Statistic & Value & Significance & $\mathrm{I}(0)$ & $\mathrm{I}(1)$ \\
\hline F-Statistic & 10.52487 & $10 \%$ & 2.08 & 3 \\
\hline K & 5 & $5 \%$ & 2.39 & 3.38 \\
\hline & & $2.5 \%$ & 2.7 & 3.37 \\
\hline & & $1 \%$ & 3.06 & 4.15 \\
\hline
\end{tabular}

Source: Author's computation from E-view 10.0

The computed F-statistic of 10.52487 in Table-3 above is greater than the upper bound (I(1)) critical value of 3.38 at the $5 \%$ level of significance. Hence, we reject the null hypothesis of no long-run relationship and conclude that there exist long-run (equilibrium) relationships among the variables of the study.

\section{ARDL Estimated Results}

It should be noted that the lag selection order in the ARDL process for the model was decided automatically based on the Akaike Information Criterion (AIC).

The ARDL estimated long-run and short-run regression results are presented in table 4.4 below.

Table-4: ARDL Estimated Long-Run and Short-Run Regression Results

\begin{tabular}{|c|c|c|c|c|}
\hline \multicolumn{5}{|c|}{$\begin{array}{l}\text { Short-Run (ECM) Regression } \\
\text { Case 2: Restricted Constant and No Trend }\end{array}$} \\
\hline Variable & Coefficient & Std. Error & t-statistic & Prob. \\
\hline $\mathrm{D}(\mathrm{INF}(-1))$ & 0.565120 & 0.104292 & 5.418634 & 0.0000 \\
\hline $\mathrm{D}(\mathrm{RR})$ & 0.000906 & 0.000966 & 0.938269 & 0.3583 \\
\hline $\mathrm{D}(\mathrm{LR})$ & -0.340677 & 0.141481 & -2.407926 & 0.0249 \\
\hline $\mathrm{D}(\mathrm{LR}(-1))$ & 0.786487 & 0.152147 & 5.169251 & 0.0000 \\
\hline $\mathrm{D}(\mathrm{MPR})$ & -0.605602 & 0.412722 & -1.467337 & 0.1564 \\
\hline $\operatorname{DMPR}(-1))$ & -2.004559 & 0.430594 & -4.655337 & 0.0001 \\
\hline DLOG(MS) & -7.826531 & 8.991548 & -0.870432 & 0.3935 \\
\hline DLOG(MS(-1)) & 32.14792 & 9.250710 & 3.475184 & 0.0021 \\
\hline CointEq(-1) & -0.958201 & 0.098954 & -9.683336 & 0.0000 \\
\hline \multicolumn{5}{|c|}{$\begin{array}{l}\text { Long-Run Coefficients } \\
\text { Case 2: Restricted Constant and No Trend }\end{array}$} \\
\hline Variable & Coefficient & Std. Error & t-statistic & Prob. \\
\hline RR & -0.002599 & 0.002338 & -1.111703 & 0.2463 \\
\hline LR & -1.159680 & 0.917114 & -1.264488 & 0.2307 \\
\hline MPR & -0.758378 & 0.612571 & -1.238025 & 0.2288 \\
\hline TBR & -0.183080 & 0.217270 & -0.842637 & 0.4085 \\
\hline LOG (MS) & 3.648867 & 0.871986 & 4.184547 & 0.0004 \\
\hline $\mathrm{C}$ & 79.11833 & 13.88839 & 5.696725 & 0.0000 \\
\hline
\end{tabular}

Source: Author's Computation from E-view 10.0

In Table-4 above, the short-run or error correction model (ECM) result is presented in the upper panel while the long-run result is presented in the lower panel. From the short-run result in the upper panel, the error correction variable (i.e, CointEq(-1)) has a negative sign. Hence, it is correctly signed. It is equally significant at the 0.05 level of significance. The coefficient of the error correction variable is -0.958201 . This implies that it has a speed of adjustment of about 95 per cent. Thus, 95 percent of any disequilibrium in the short-run is adjusted to long-run equilibrium within a year.

\section{Post Estimation Tests}

Since the ARDL model is a linear regression model, the assumptions of the Classical Linear Regression Model (CLRM) must be fulfilled. Some of these assumptions are linearity, homoscedasticity, serial independence, and normality. The results and decisions for the tests of these assumptions are presented in Table-5 below. For each of tests, if the P-value is greater than 0.05 , the null hypothesis will not be rejected. 
Table-5: Post Estimation Tests Results

\begin{tabular}{|l|l|l|l|}
\hline Test & Value & Prob. & Decision \\
\hline Linearity (Ramsey Reset) Test & & & \\
t-statistic & 4.564226 & 0.5302 & Accept (model correctly specified) \\
F-statistic & 20.83216 & 0.5302 & \\
\hline Breusch-Godfrey LM Test & & & Accept (No Serial Correlation) \\
F-statistic & 0.734461 & 0.4923 & \\
\hline $\begin{array}{l}\text { Heteroscedasticity (Glejser) Test } \\
\text { F-statistic }\end{array}$ & 0.777280 & 0.6817 & Accept (Residuals have constant variance) \\
\hline $\begin{array}{l}\text { Normality (Jarque-Bera) Test } \\
\text { F-statistic }\end{array}$ & 1.294656 & 0.523443 & Accept (data normally distributed) \\
\hline
\end{tabular}

Source: Author's Computation from E-view 10.0

\section{DiscuSSION OF FINDINGS} this section.

The behaviour of the variables in the long-run and short-run ARDL model presented in Table-4 are discussed in

\section{Estimated Long-Run Results}

The estimated long-run regression result showed that reserve requirement $(R R)$ has insignificant negative impact on inflation rate in Nigeria. This implies that an increase in the reserve requirement by the CBN will insignificantly reduce inflation in Nigeria. Similarly, liquidity ratio (LR), monetary policy rate (MPR) and Treasury Bill Rate (TBR) all have weak negative impact on inflation in Nigeria. The implication is that if the CBN raises the LR, MPR and TBR, it will result in an insignificant reduction in the rate of inflation in Nigeria. On the other hand, money supply (MS) has significant positive impact on inflation in Nigeria. Consequently, an increase in the supply of money will aggravate inflation and vice versa.

\section{Estimated Short-Run Result}

From the short-run regression result, inflation (INF) lagged by one period has strong positive impact on inflation in the current period. This shows that inflation in the previous period has strong positive shock on inflation in the current period.

Reserve requirement in the current period has weak positive impact on inflation in the same current period. Liquidity ratio in the current period has strong negative effect on inflation in Nigeria. However, liquidity ratio lagged by one period has significant negative impact on the rate of inflation in the current period.

Monetary policy rate in the current period produces weak negative impact on inflation in the current period. On the other hand, monetary policy rate lagged by one period significantly and negatively affects the inflation rate in the current period. Similarly, money supply in the current period has insignificant negative impact on inflation in the current period. However, money supply in the previous period has strong positive effect on inflation in Nigeria.

\section{Conclusions}

Based on our findings, the following conclusions were drawn from the study.

(i) Reserve requirement has weak reducing effect on inflation in Nigeria

(ii) Liquidity ratio insignificantly reduces inflation in Nigeria

(iii) Monetary policy rate insignificantly reduces inflation in Nigeria

(iv) Treasury bill rate reduces inflation in Nigeria, but its influence on inflation is weak

(v) Money supply strongly aggravates inflation in Nigeria

\section{Policy Recommendations}

Based on the conclusions drawn from the study, we recommend the following policy measures to improve the performance of monetary policy instruments on the control of inflation in Nigeria.

1. It is generally believed that shallow financial systems weaken the transmission of monetary policy actions thereby, weakening the effectiveness of monetary policy actions. Hence, to improve the efficacy of monetary policy instruments in tacking inflation in Nigeria, there is the need to develop and deepen the financial system. To this end, key financial deepening indicators such as money supply/GDP ratio, credit to private sector as a ratio of GDP, banks' liquidity-GDP ratio, etc. should be improved upon 
2. There is the need for timely implementation of monetary policy actions in Nigeria to avoid the lag-in-effects of the policy actions. To this end, data on relevant macroeconomic variables should be collected and processed in accurate and timely manner.

3. The Central Bank of Nigeria should ensure moderate increase in money supply. Thus, any increase in money supply should be consistent with GDP growth in order to reduce inflation caused by monetary expansion.

4. There should be proper co-ordination of monetary and fiscal policies. To achieve this, the CBN should be proactive in determining the stance of the fiscal authorities on fiscal policy. This will help to reduce the conflicts in monetary and fiscal policy actions.

\section{REFERENCES}

1. Umaru, A., \& Zubairu, A. A. (2012). Effect of inflation on the Nigerian economy (an empirical analysis). International Journal of Business and Social Science, 3 (10), 183-191.

2. Ajayi, S. I., \& Ojo, O. O. (1981). Money and banking: Analysis and policy in the Nigerian context. George Allen and Unwin.

3. Anyanwu, J. C (1993). Monetary economics: Theory, policy and institutions. Hybrid Publishers Ltd.

4. Tule, M. K., Ogundele, O. S., \& Apinran, M. O. (2018). Efficacy of monetary policy instruments on economic growth: Evidence from Nigeria. Asian Economic and Financial Review, 8 (10), 1239 - 1256. https://doi.org/10.18488/journal.aefr.2018.810.1239.1256.

5. Apere, T. O., \& Karimo, T. M. (2014). Monetary policy effectiveness, output growth and inflation in Nigeria. International Journal of Economics, Finance and Management, 3 (6), 301 - 307.

6. Onwachukwu, C. I. (2014). Impact of monetary policy on inflation control in Nigeria. MPRA Working Paper No. 67087.

7. Akarara, E. A., \& Azebi, O. I. (2018). The effectiveness of monetary policy in the control of inflation: An ecm approach. Journal of Economics and Finance, 9 (1), 86 -94. https://10.9790/5933-0901028694.

8. Adodo, F. L., Akindutire, O. R., \& Ogunyemi, J. K. (2008). Monetary policy and control of inflation in Nigeria. International Journal of Management, IT and Engineering,8 (12), 154 - 170.

9. Chinaemerem, O. C., \& Akujuobi, L. E., (2012). Inflation targeting and monetary policy instruments: Evidence from Nigeria and Ghana. Arabian Journal of Business and Management Review, 1(11), 52-81.

10. Odior, E. S. (2013). Monetary policy, bank lending and inflation in Nigeria: Var approach. Kashere Journal of Humanities and Social Science, 1, (1\&2), $134-149$.

11. Ngerebo, T.A. (2016). Monetary policy and inflation in Nigeria. International Journal of Finance and Accounting, 5 (2), 67 -76. https:doi.org/10.5923/j.ifa.20160502.01.

12. Abdullahi, Y.Z., \& Kime, M. M. (2016). Money Supply Growth and its Inflationary effects in Nigeria. Nigerian Deposit Insurance Corporation (NDIC), Quarterly Review, 29 (3), 70 - 96.

13. Ahuja, H. L. (2013). Modern economics (17 ed.). S. Chand Publishing Ltd.

14. Iddrisu, S., K., \& Amidu, M. (2017). The impact of monetary policy on stock market performance: Evidence from twelve (12) African countries. Research in International Business and Finance, 42; 1372-1382: https://doi.org/10.106/j.ribaf.2017.07.075.

15. Adesina, J. M., Nwidole, M. B., \& Amadi, A. M. (2018). Monetary policy and financial performance of Nigerian deposit money banks. Asian Economic and Financial Review, 8 (7), $853 \quad-\quad 869$. https://10.184/journal.aefr.2018.87.853.869.

16. Osakwe, A. C., \& Chukwunielu, J. I. (2019). Monetary policy and stock market performance in Nigeria. EPRA International Journal of Research and Development, 4 (5), 58 -65.

17. Shaseen, R. (2020). Credit market conditions and impact of monetary policy in a developing economy context. International Economics and Economy Policy,7, 409 - 425. https://doi.org/10.1007/S10368 - 020.00461.7.

18. Barro, R. J., \& Grilli, V. (1994). European macroeconomics. Macmillan.

19. Northgate, I. H. M. S. (2009). BOARD MEETING ACTION TRACKER. Policy, 268, 24.

20. Ohale, L., \& Onyema, J. L. (2002). Foundations of macroeconomics. Springfield Publishers Ltd.

21. Partachi, I. S. \& Mija, S. (2015). Monetary policy instruments for macroeconomic stabilization. Prodecia Economics and Fiance, 20, 485-493. https://doi.org/10.1016/S2212-5671(15)00100.

22. Nnanna, O. J. (2001). Monetary policy framework in Africa: The Nigerian experience. CBN.

23. Odozi, V. A. (1995). The conduct of monetary and banking policies by the central bank of Nigeria. CBN Economic and Financial Review, 33 (1), 9-13.

24. Central Bank of Nigeria (1979). Twenty years of central banking in Nigeria; $1959-1979$. CBN.

25. Ogwuma, P. (1994). The control of the monetary and banking system by the Central Bank of Nigeria. Central Bank of Nigeria Economic and Financial Review, 32 (1), 5 - 15.

26. Okotori, T. W., (2019). The dynamics of monetary policy and inflation in Nigeria. Journal of Economics and Finance, 10 (2), 37-49. https://doi.org/10.9790/5933-1002013749.

27. Ogunmuyiwa, M. S., (2020). Managing the inflation problem in Nigeria using the fisco-monetary approach. Athens Journal of Business \& Economics, 6 (3), 239-252. https://doi.org/10.30958/ajbe.6-3-4. 
28. Oke, B. A. (1995). The conduct of monetary policy in the 1980's and prospects in the 1990's. Central Bank of Nigeria Economic and Financial Review, 33 (4), 289 - 294.

29. Ogenyi, A. O., \&Umeh, J. C., (2019). Determinants of inflation volatility in Nigeria, 1980-2010. A Paper Presented at the $6^{\text {th }}$ African conference of Agricultural Economists, September 23-26, Abuja, Nigeria.

30. Orajaka, U. P., \& Okeke, C. P. (2017). Inflationary trend and its impact on Nigeria stock exchange market. International Journal of Academic Research in Business and Social Sciences, 7 (11), 127-140. https://doi.org/10.6007/IJARBSS/V7-iII/3445.

31. Femi, O. T., (2014). Inflation and demand for money in emerging economies: Evidence from Nigeria. Journal of Economics and Sustainable Development, 5(8), 77-87.

32. Bawa, S., \& Abdullahi, I. S. (2012). Threshold effects of inflation on economic growth in Nigeria. CBN Journal of Applied Statistics, 7 (1), 43-63.

33. Central Bank of Nigeria (2010). Macroeconomic model of the Nigerian economy. www.cbn.gov.ng/out/2015RSDmacroeconometric.

34. Humphrey, T. M. (1974). The quantity theory of money: Its historical evolution and role in policy debates. Federal Reserve Bank of Richmond Economic Review, 60, 2 - 19.

35. Volckart, V. (1997). Early beginnings of the quantity theory of money and their context in Polish and Prussian monetary policies, c.1520 - 1550. The Economic History Review, 50 (3), 430 - 449. https://10.1111/14680289.000063.

36. Onoh, J. O., \& Obioma, J. (2017). A comparative study of monetarist and Keynesian theories on inflation and money supply in Nigeria. International Journal of Economics and Financial Management, 2 (1) 56 -70.

37. Frisch, H. (1984). Monetarist inflation theory. Cambridge University Press.

38. Bresser-Pereira, L. C. (2012). Structuralist macroeconomics and the new developmentalism. Brazilian Journal of Political Economy, 32 (3), 347-366. https://doi.org/10.1590/S0101-31572012000300001.

39. Missio, F., Jayme, F. G., \& Oreiro, J. L. (2015). The structuralist tradition in economics: Methodological and macroeconomics aspects. Brazilian Journal of Political Economy, 35 (2), 147-466. https://dx.doi.org/10.1590/0101$31572015 \mathrm{~V} 35 \mathrm{n} 0 \mathrm{za} 03$.

40. Asshoff, S., Belke, A., \& Osowski, T., (2020). Unconventional monetary policy and inflation expectations in the Euro area. Centre for European Policy Studies, Working Paper No. 2020/01.

41. Dabrowski, M., Paczynski, N., \& Rawdanowicz, L. (2002). Inflation and monetary policy in Russia: Transition experience and future recommendations. Center for social and Economic Research, Warsaw, Working Paper No. 241

42. Muco, M., Sanfrey, P., \& Taci, A., (2004). Inflation, exchange rates and the role of monetary policy in Albania. European Bank for Reconstruction and Development, Working Paper No. 88.

43. Honore, T. O. (2018). Monetary policy and inflation: Empirical evidence from Cameroun. International Journal of economics, Finance and Management Sciences, 6 (5), 200 -207. https://doi.org/10.11648/j.ijefm.20180605.11

44. Doan, V. D. (2019). Money supply and inflation impact on economic growth. Journal of Financial Economic Policy, 12 (1), 121 - 136. https://doi.org/10.1108/JFEP - 10-2018-052.

45. Ogbonna, B. C., (2010). Inflation, exchange rate and efficacy of monetary policy in Nigeria: The empirical evidence. International Scientific Journal, 2 (1), 40-53. https//doi.org/10.7336/academicus. 2016.13.03.

46. Nwosa, P. I., \& Oseni, I. O. (2012). Monetary policy, exchange rate and inflation rate in Nigeria: A cointegration and multivariate vector error correction model approach. Research Journal of Finance and Accounting, 3 (3), 62 69.

47. Nwachukwu, P. O., Dibie, A. C., \& Ogubo, A. P. (2014). Effectiveness of monetary policy in reducing inflation in Nigeria (1970 - 2013). Journal of Economics and Sustainable Development, 5, (13), 73 -81.

48. Ikezam, N. D. (2018). Money Supply and Inflation: Disaggregated time-series evidence from Nigeria. American Finance and Banking Review, 2 (1), 54 - 63. Hhttps://doi.org/10.46281/amfbr.v2il.129.

49. Usman, K., (2019). Impact of monetary policy on controlling inflation in Nigeria. Economic Review, 2(3), 30-42.

50. Pesaran, M. H., Shin, Y., \& Smith, R. J. (2001). Bounds testing approaches to the analysis of level relationships. Journal of applied econometrics, 16(3), 289-326.

CITATION: Clement Korgbeelo \& Deebii Nwiado (2021). Monetary Policy Instruments and the Control of Inflation in Nigeria: A Time-Series Analysis. South Asian Res J Human Soc Sci, 3(2): 71-80. 